\title{
Analysis of Capillary Fluid Flow Rate by Vibration on a Small Vessel Model*
}

\author{
Yukari FukAGAWA ${ }^{1}$, Miki OTSU' ${ }^{1}$, Masahiro NAKANO ${ }^{2}$ and Takashi MAKI ${ }^{2}$

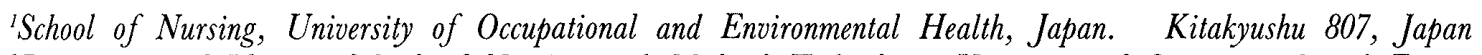 \\ ${ }^{2}$ Department of Physics, School of Nursing and Medical Technology, University of Occupational and Environmental \\ Health, Japan. Kitakyushu 807, Japan
}

Abstract: In order to estimate the direct effect of the physical vibration on the peripheral blood flow rate, we measured the water flow rate in a silicon capillary tube whose end was vibrated. Three types of vibration were added to the tube and the frequency of the vibration covered $1-2000 \mathrm{~Hz}$. It is shown that the water flow rate reduces under the vibration and this reduction strongly depends on the frequency and the type of the vibration. The main reason for this dependence is shown to be as follows. The vibration stretches the tube and the average length of the tube is longer under the vibration than when under no vibration, and the average tube radius is smaller under the vibration. This causes the reduction of the flow rate under vibration. Because the stretch of the tube strongly depends on the frequency and the type of the vibration, the above dependence of the water flow rate finally appears.

Key words: flow rate, vibration effects, frequency dependence.

(Received 15 February 1986)

\section{Introduction}

The vibrational hazards in peripheral blood vessels as an occupational origin is caused by using vibrating tools. In order to estimate the direct effects of physical vibration, we have made a model experiment. In our experiment, water was employed instead of blood and the silicon capillary tube was employed instead of blood vessels. Physical qualities of the silicon capillary tubes are similar to blood vessels. The silicon tube was vibrated by the following three types of vibration modes; 1) sine wave of transverse vibration to the flow axis, 2) rectangular wave of transverse vibration, and 3) sine wave of longitudinal vibration. The observed decreases of water flow rate due to vibration greatly depend on the type of the vibrations and the frequency (Fukagawa et al., 1986; Maki et al., 1986.) In this paper, we summarize the results of our experiment and analyze the reason why the decreases of flow rate strongly depend on the frequency and the type of the vibrations.

$\dagger$ Present address: St. Mary School of Nursing, Kurume 830, Japan.

* This work was supported in part by Grant-in-Aid for Industrial Ecological Research of UOEH. 


\section{Experimental Method}

The experimental apparatus is shown in Fig. 1. In this model experiment, water was used instead of blood. In order to simulate the blood vessels, soft silicon capillary tubes were adopted, which have the same elasticity as blood vessels. The inner diameter of the tube was measured to be $0.9819 \pm 0.0047 \mathrm{~mm}$ by means of pouring mercury through it. The Young modulus of the tube was measured to be $3.31 \times 10^{7}$ $\mathrm{dyn} / \mathrm{cm}^{2}$. The upper end of the silicon capillary tube was fixed and the lower end was vibrated by a 4 inch- 10 watt speaker. The pressure difference in the tube was kept constant. The water flowed into the scilicon capillary tube and dropped into a weight detector. We measured the water flow rate in a constant time duration both with vibration and without vibration. The difference of the two water flow rates represents the effects of the vibrations. The three kinds of vibration modes were added to the tube; 1) sine wave of transverse vibration to flow axis, 2) rectangular wave of transverse vibration, and 3) sine wave of longitudinal vibration. The range of the frequency was between 1 and $2000 \mathrm{~Hz}$. The acceleration of the vibration is over $10 \mathrm{G}$ as shown in Fig. 2. This acceleration is larger than that of usual vibrating tools.

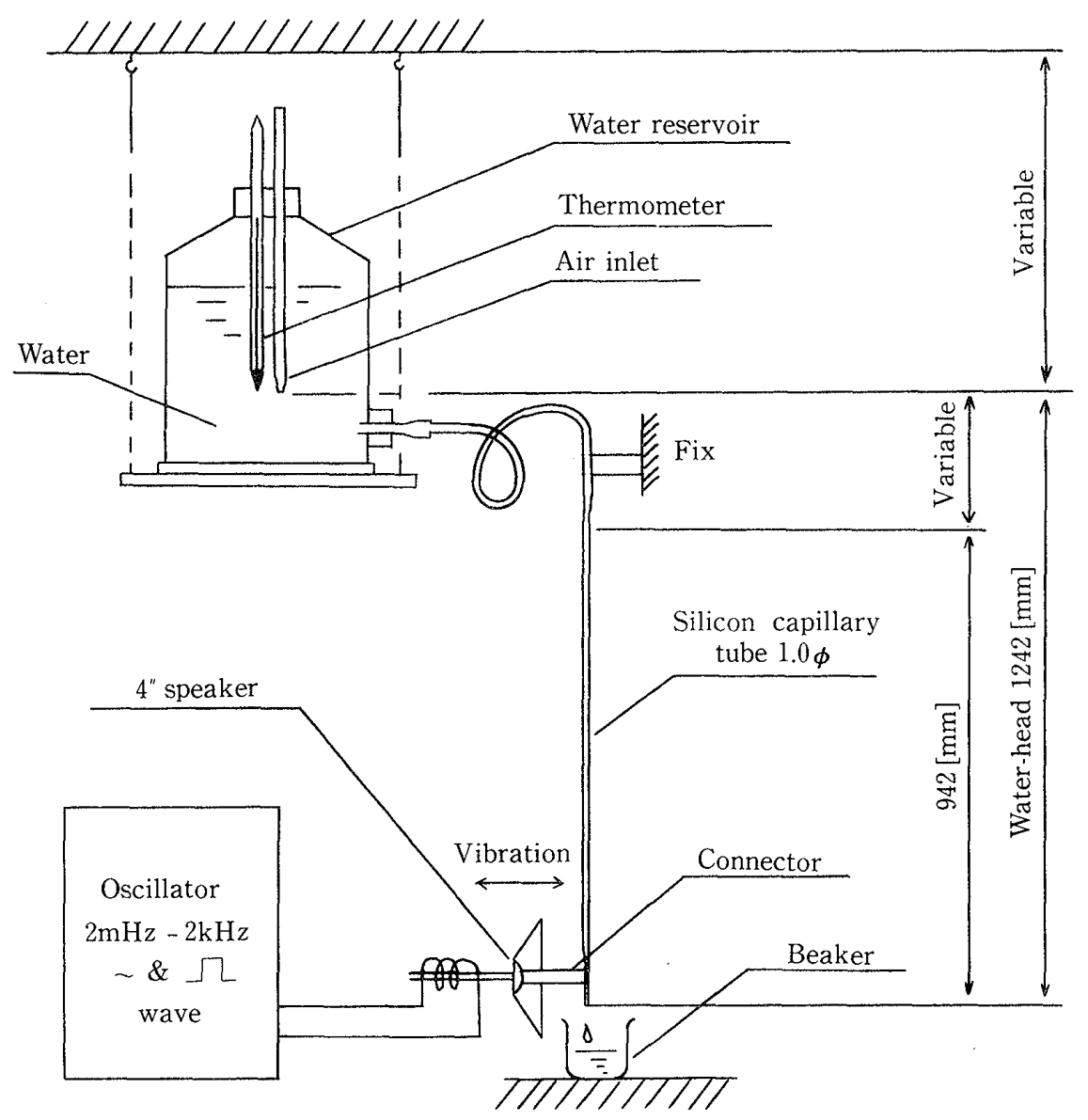

Fig. 1. Schematic experimental arrangement used to measure the flow rate of water through a silicon capillary tube by low frequency vibration. 


\section{Results and Discussion}

Compared to the case when threr is no vibration, the water flow rate decreases when the vibrations are added to the tube. The ratio of the water flow rate is shown in Fig. 3 for the transverse vibration, and in Fig. 4 for the longitudinal vibration. Corrections of temperature, density and viscosity to the flow rate were taken into account.

In the transverse vibration case, as shown in Fig. 3, 1-1.4\% decrease of the flow rate was recognized both for sine and rectangular waves between $10 \mathrm{~Hz}$ and 70 $\mathrm{Hz}$. On the other hand, a large decrease such as $8-10 \%$ decrease between $20 \mathrm{~Hz}$ and $90 \mathrm{~Hz}$ was observed in the longitudinal vibration case and the decrease strongly depended on the frequency of the vibration. It should be noted that there was a regularity in the frequencies causing the dip of the flow. These frequencies are approximately expressed by $f_{0}$ multiplied by integer, where $f_{0}$ is the minimum frequency among those causing dips of the flow (see Table 1). This situation suggests that the vibration of the silicon tube has eigenfrequencies.

In order to investigate the frequency dependence of the water flow rate, the following formula is applied,

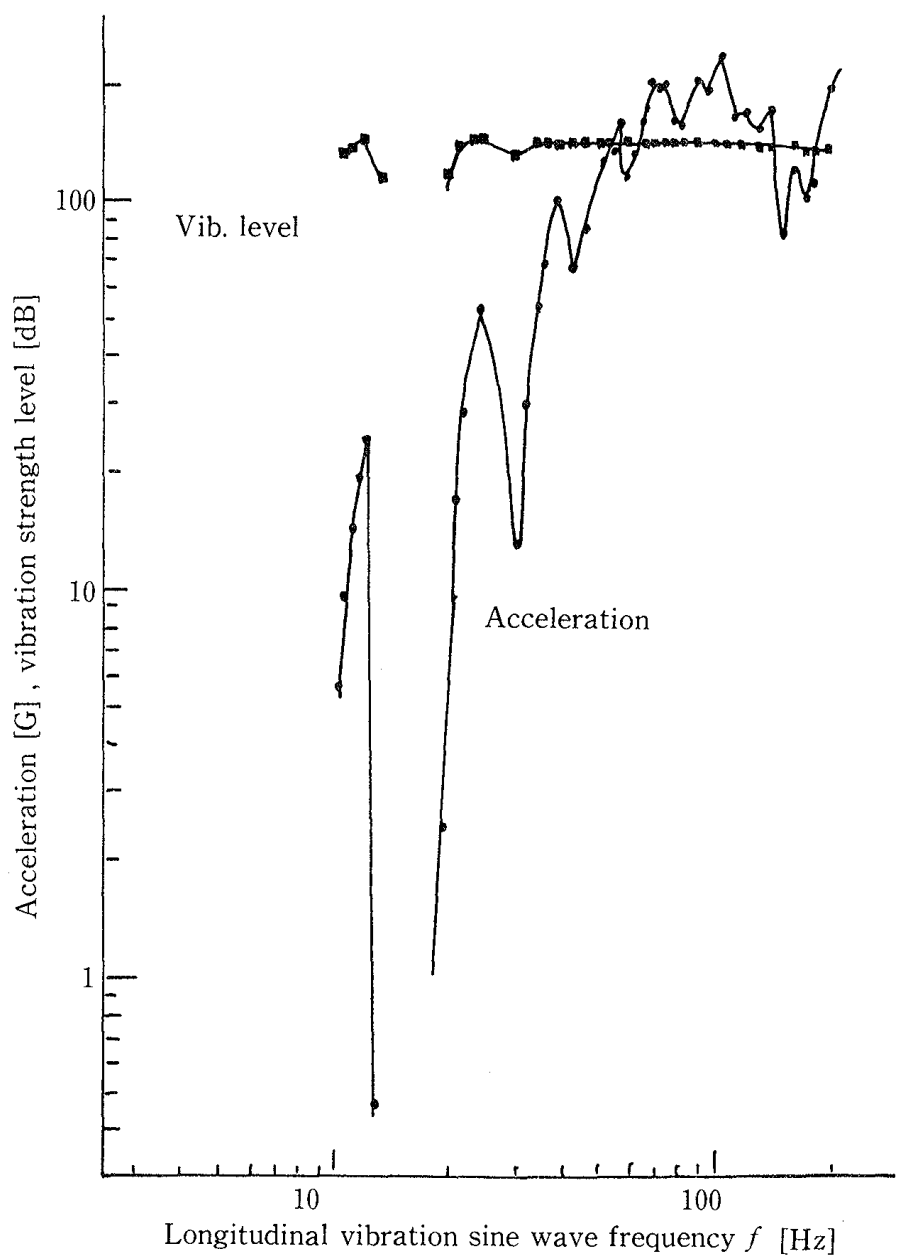

Fig. 2. Acceleration and vibration strength level for longitudinal sine wave vibration. 


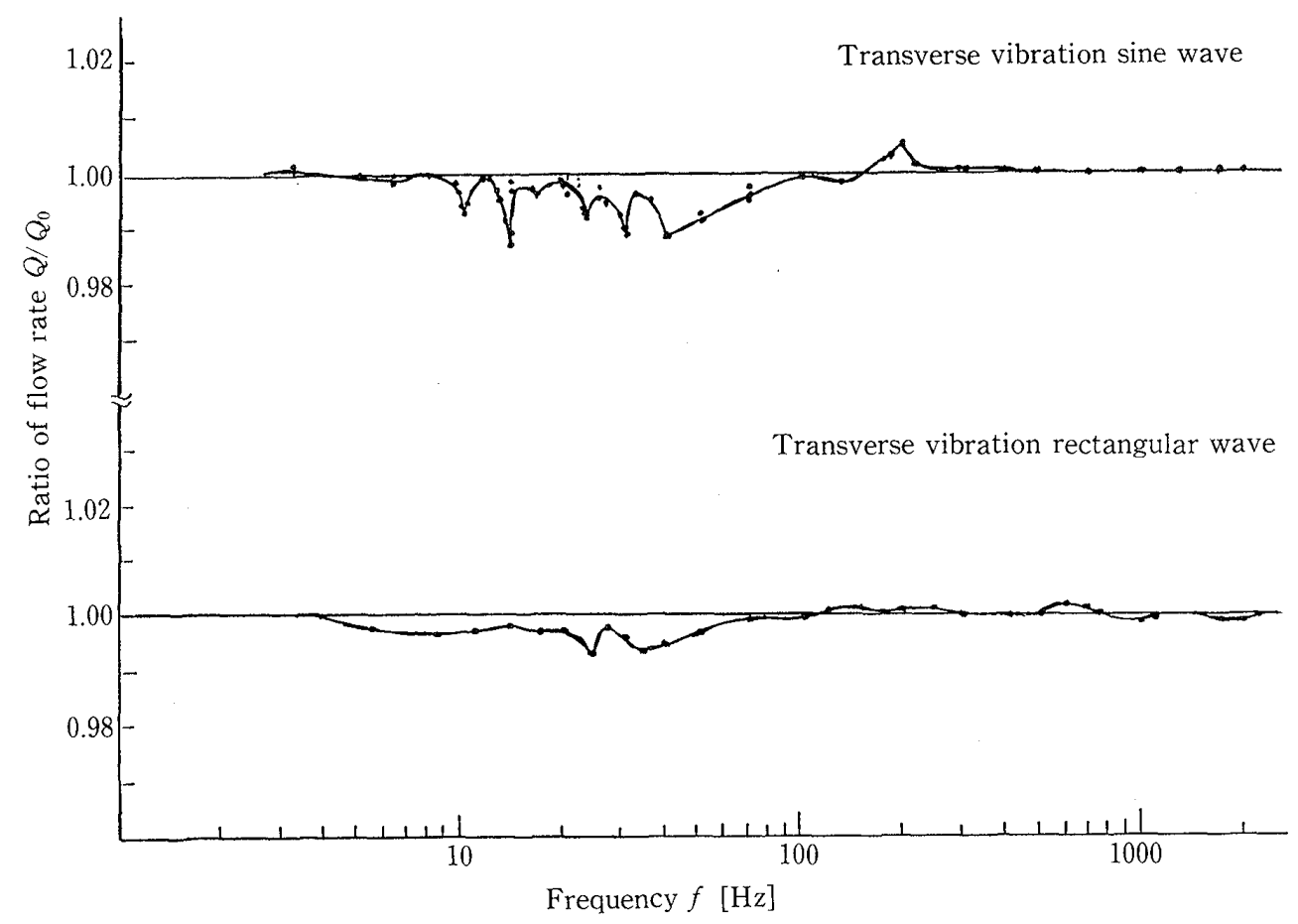

Fig. 3. The ratio of flow rate, $Q / Q_{0}$, of water versus frequency $f . Q$ and $Q_{0}$ mean the flow rate by vibration and non-vibration, respectively. In the upper part, the vibrational mode is a sine wave of transverse vibration. In the lower part, the vibrational mode is a rectangular wave of transverse vibration.

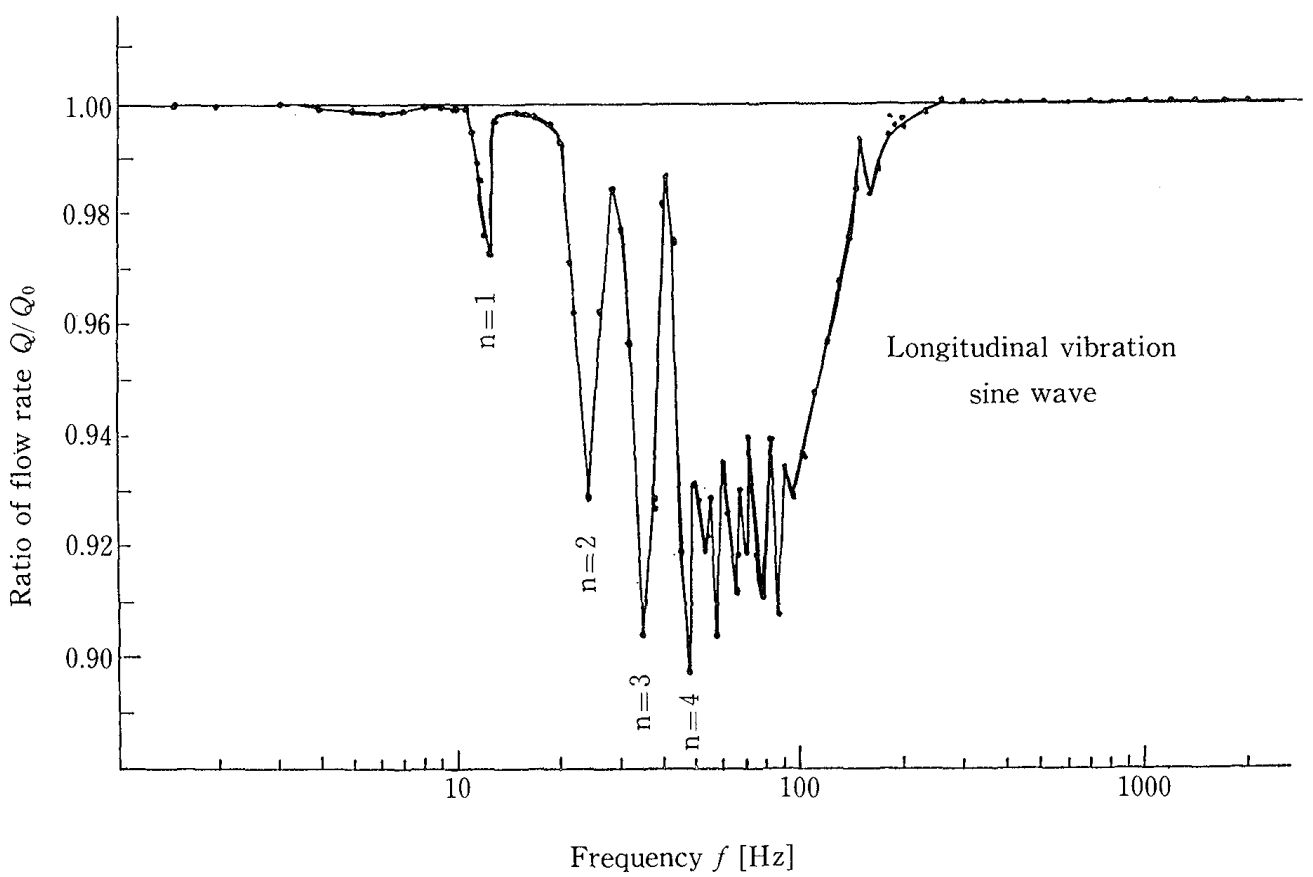

Fig. 4. Same as in Fig. 3., but for the vibrational mode being a sine wave of longitudinal vibration. 
Table 1. List of natural vibrations used in eq. 1. The symbols, $f_{\mathrm{n}}$ represents eigenfrequency $[\mathrm{Hz}], \Gamma_{\mathrm{n}}$ is width $[\mathrm{Hz}]$ and $A_{\mathrm{n}}$ is the amplitude of the natural vibration

\begin{tabular}{rrcc}
\hline $\mathrm{n}$ & $f_{\mathrm{n}}[\mathrm{Hz}]$ & $\Gamma_{\mathrm{n}}[\mathrm{Hz}]$ & $A_{\mathrm{n}}$ \\
\hline 1 & 12.0 & 1.2 & 0.027 \\
2 & 24.0 & 3.3 & 0.065 \\
3 & 34.7 & 3.0 & 0.100 \\
4 & 45.4 & 3.0 & 0.110 \\
5 & 52.0 & 5.0 & 0.045 \\
6 & 56.0 & 5.0 & 0.060 \\
7 & 64.0 & 5.0 & 0.056 \\
8 & 68.0 & 3.0 & 0.055 \\
9 & 76.0 & 6.0 & 0.100 \\
10 & 86.0 & 4.0 & 0.082 \\
11 & 96.0 & 6.5 & 0.065 \\
12 & 102.0 & 4.0 & 0.040 \\
13 & 110.0 & 6.0 & 0.040 \\
14 & 120.0 & 6.5 & 0.030 \\
15 & 130.5 & 20.0 & 0.025 \\
16 & 165.0 & 10.0 & 0.035 \\
\hline
\end{tabular}

$$
R=1-\sum_{\mathrm{n}} \frac{A_{\mathrm{n}}\left(\frac{\Gamma_{\mathrm{n}}}{2}\right)^{2}}{\left(f-f_{\mathrm{n}}\right)^{2}\left(\frac{\Gamma_{\mathrm{n}}}{2}\right)^{2}}
$$

where, $f_{\mathrm{n}}$ are the eigenfrequencies, $\Gamma_{\mathrm{n}}$ are the widths of the eigenvibrations and $A_{\mathrm{n}}$ are amplitudes of the normal vibrations. These quantities are listed in Table 1 and the comparisons between the experimental flow rate and the calculated one are shown in Fig. 5. Thus the flow rate can be well expressed as the superposition of normal vibrations.

The water flow rate $Q[\mathrm{cc} / \mathrm{sec}]$ is expressed by Hagen-Poiseulle's laminar flow formula together with two modification terms, when it is a laminar flow and the tube is not vibrated,

$$
Q=\frac{\pi r^{4}}{8 \mu l} \rho_{g h}+\frac{\pi^{2} r^{2}}{2 \mu l} \rho_{g h v}-\frac{8 \pi \mu l}{1.12 \rho}
$$

where $r$ is a radius of the tube, $\rho$ is the density of the water, $g$ is the acceleration of the earth gravity, $h$ is the height from the drop spot to the level of atmosphere pressure, $l$ is the length of the tube and $\mu$ is the viscosity of the water. In order to identify whether the flow is a laminar or turbulent flow, Reynold's number $R e$ is calculated both for vibration and for no vibration. The estimated value is from 370 to 400 . This indicates the flow is a laminar flow because the value is lesser than the critical value 2000. Thus we assume that the formula in eq. 2 holds in our case even though the silicon tube is 


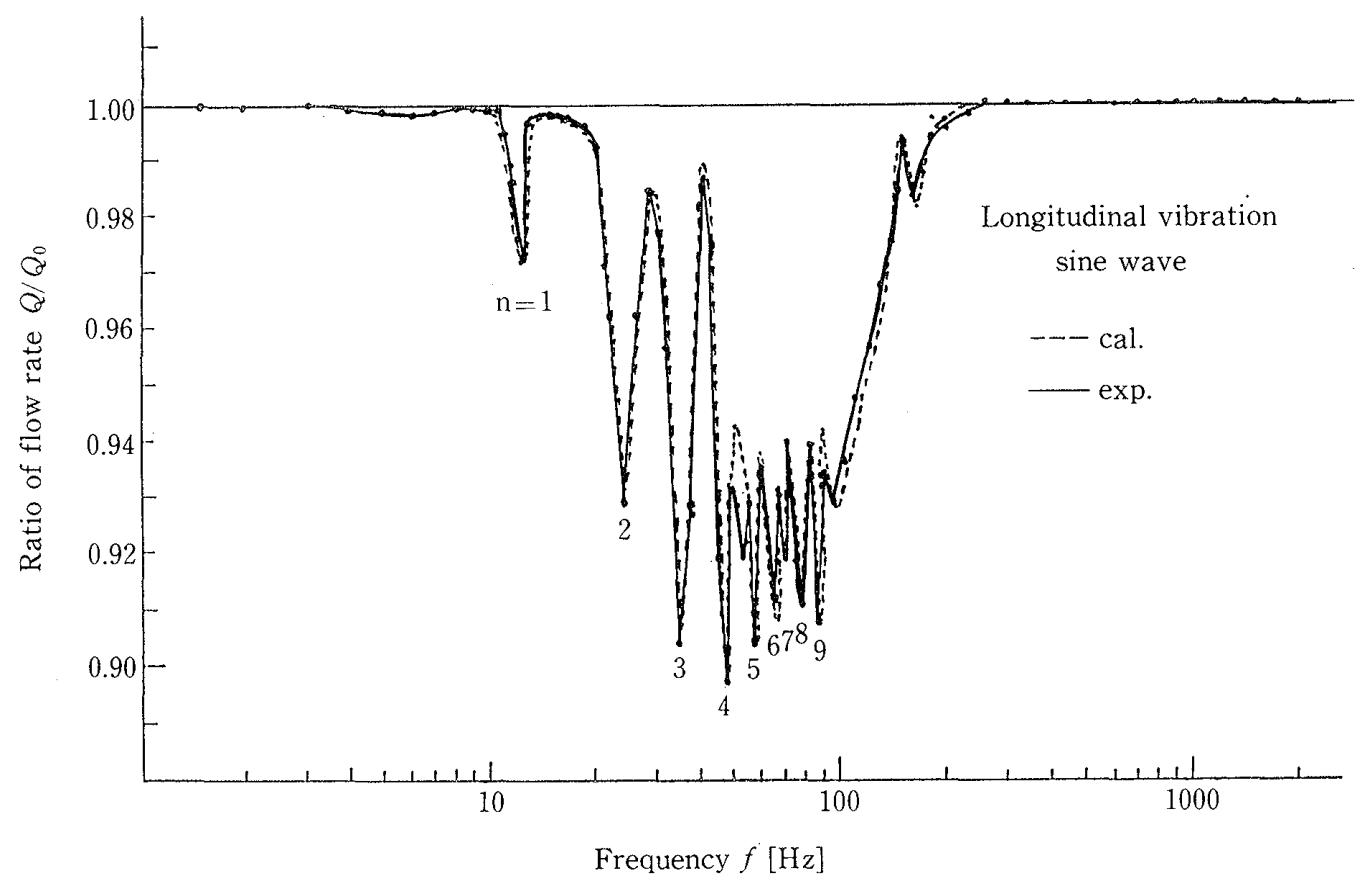

Fig. 5. Comparison between the experimental data of flow rate and the calculated one for the longitudinal vibration case. The continued line is for the experimental data and the dotted line is the calculated values.

under the accelerated motion. The important point in eq. 2 is that the flow rate is proportional to the fourth power of the radius. Thus the radius is the most important quantity affecting the flow rate. Actually, the radius varies under vibrational motion. The mechanism is as follows. When the silicon tube was vibrated, resonances are observed at some frequencies. The amplitude of the tube vibration has a maximum value in the resonance and then the tube is stretched. As a result, the radius becomes smaller than the natural one.

The following data verifies the above mechanism. Firstly, we measured the flow rate versus the length of the tube as shown in Fig. 6. From this data, we deducted the variation of the tube radius using the expression,

$$
\frac{r}{r_{0}}=\left(\frac{1 Q}{l_{0} Q_{0}}\right)^{\frac{1}{4}}
$$

Thus we deduced the relation between the tube radius and the length.

Secondly, we measured the maximum amplitude of the vibration of the tube when the tube was vibrating at the eigenfrequency and we calculated the length of the tube assuming the shape of the vibration is a sine curve. Figure 7 shows the ratio of the length at the eigenfrequency for a longitudinal vibration case. We noticed that the frequency dependence of the ratio of the tube length was similar to that of the ratio of flow rate. This suggests that the mechanism mentioned above is correct.

Furthermore, we measured the variation of flow rate and the tube length more pre- 
Ratio of tube length $/ / l_{0}$

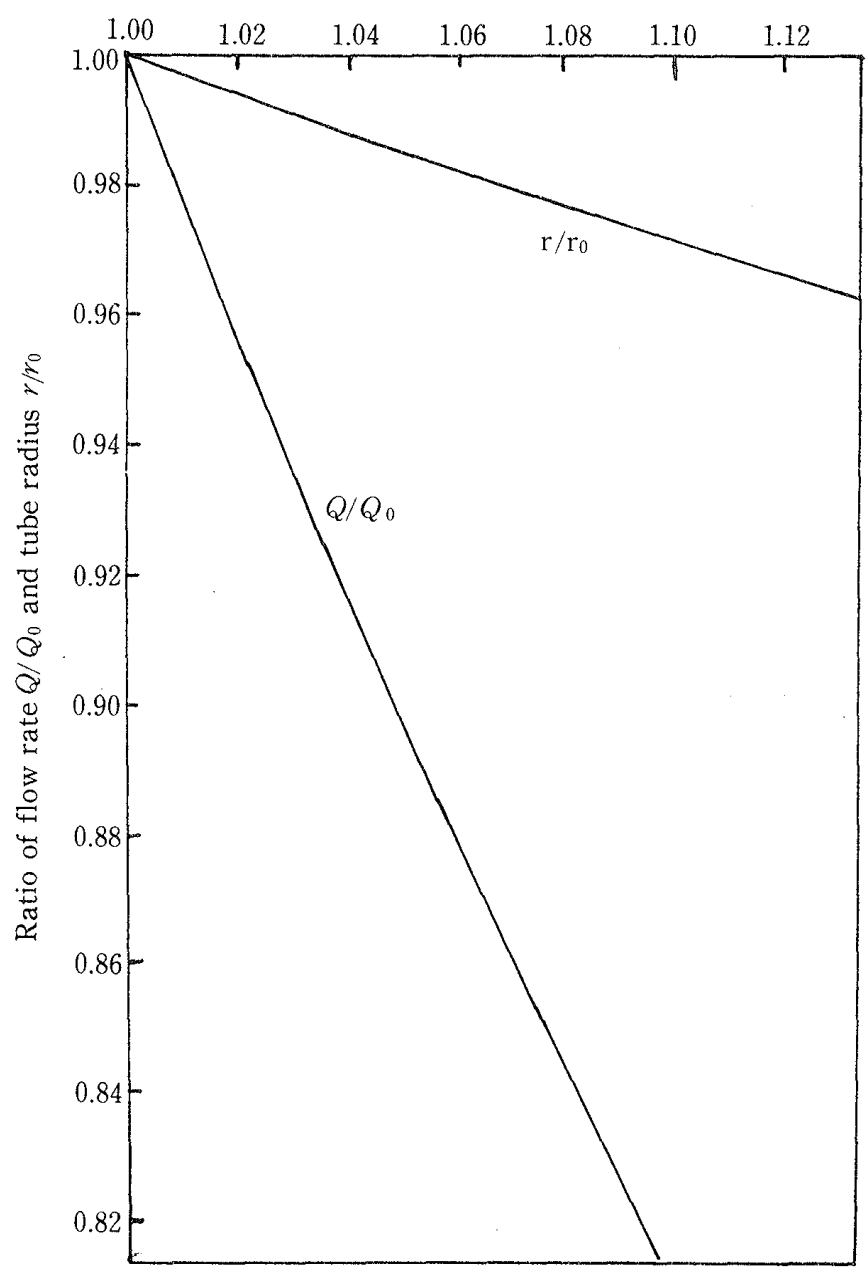

Fig. 6. Dependence of flow rate $Q$ and radius $r$ on the tube length $l$ under no vibration.

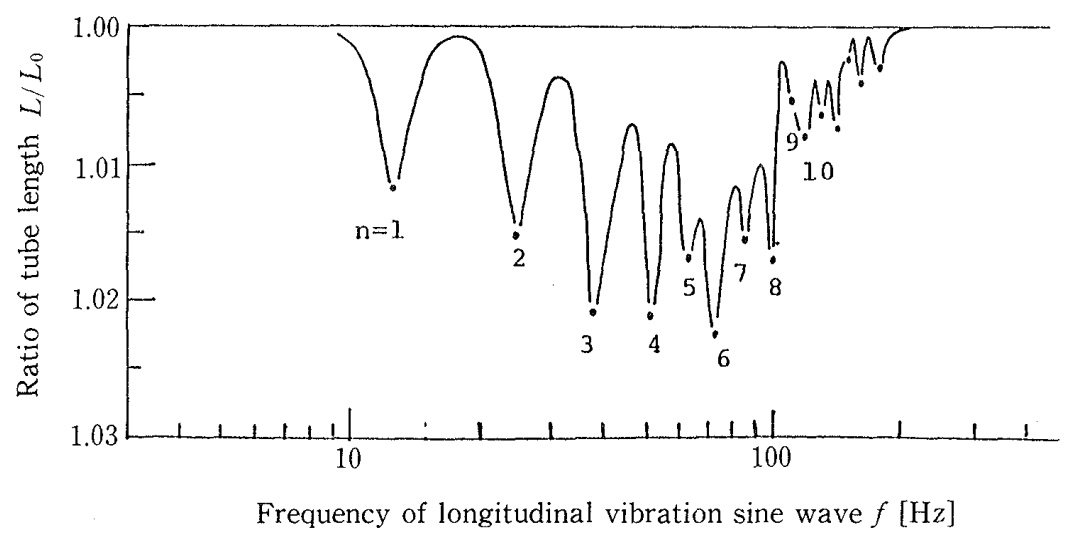

Fig. 7. Frequency dependence of the tube length for the longitudinal vibration. 
cisely around the frequency of $\mathrm{f}-12 \mathrm{~Hz}$. The data shown in Fig. 8 also indicate that the reduction of the flow rate is due to the variation of the radius caused by the stretching of the tube. In fact we calculated the tube length of the resonances when the vibration was transversal as shown in Fig. 9. This figure clearly shows that the variation of the length (radius) of the tube was less in the transverse vibration than in the longitudinal one.

\section{Conclusion}

The frequency dependence of the water flow rate through the silicon tube was measured while the silicon tube was vibrating. The flow rate strongly depends on the frequency of the vibration. The flow rate in the transverse vibration is much less than during the longitudinal vibration. The main reason for the flow rate depending on the frequency and the type of the vibration was investigated. It was verified that the vibration causes a variation in the length of the silicon tube and this variation of the length causes a

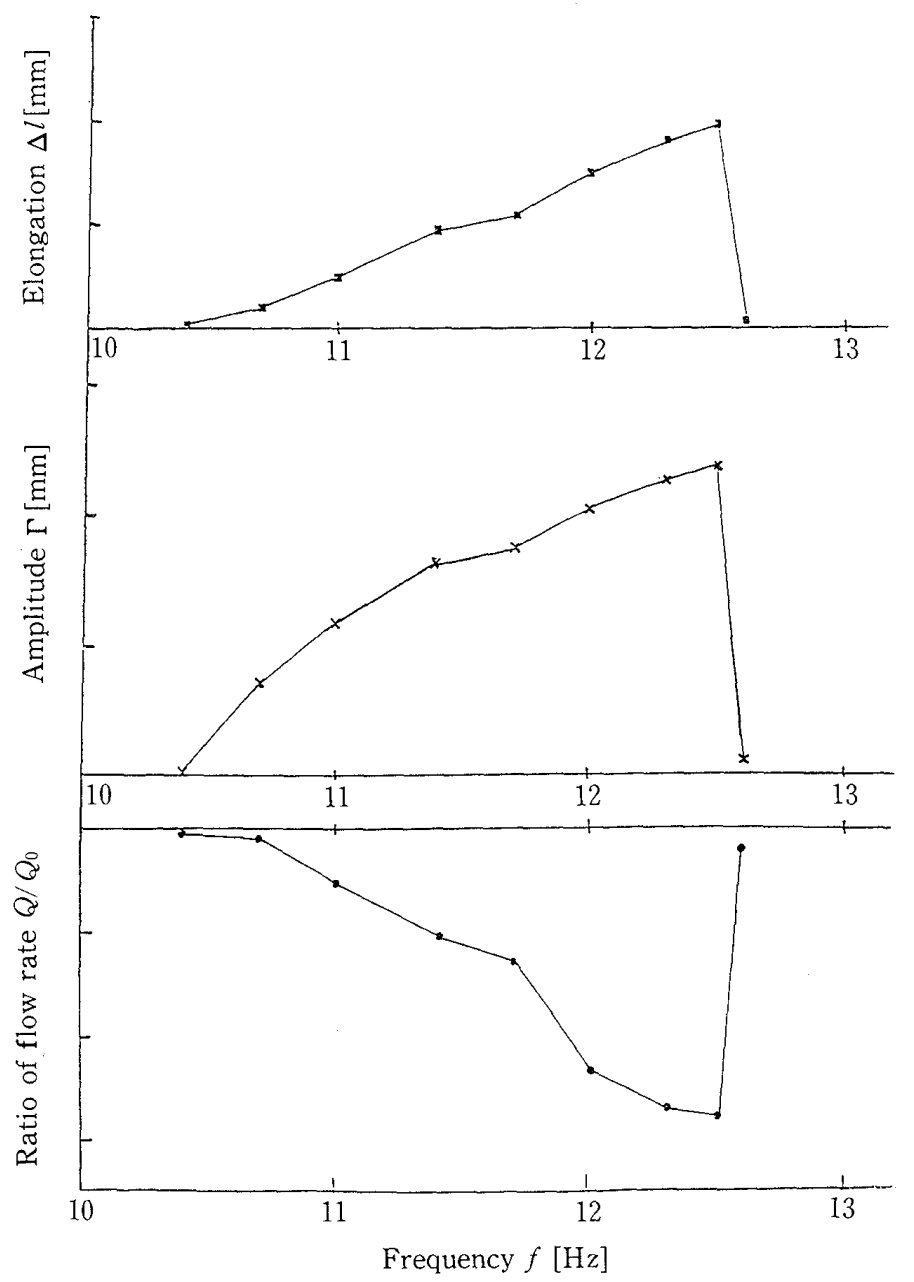

Fig. 8. Frequency dependence of flow rate, amplitude and elongation for longitudinal vibration whose frequency is nearly $12 \mathrm{~Hz}$. 


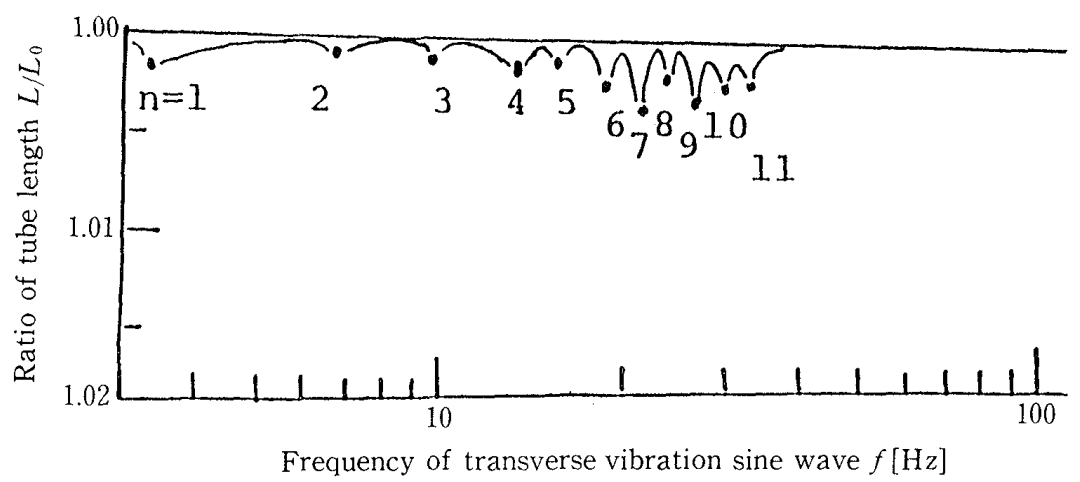

Fig. 9. Frequency dependence of the tube length for the transverse vibraton.

variation of the tube's radius. Then the flow rate strongly depends on the frequency and the type of the vibration because of the variation of the tube radius. Thus we conclude that the vibration causes the reduction of the flow rate due to the reduction of the radius of the tube. We suggest the possibility that the vibrating tools change the radius of the peripheral blood vessels and also cause the reduction of the blood flow rate.

\section{References}

Fukagawa, Y., Otsu, M., Nakano, M., et al. (1986): Observations of capillary fluid flow rate by vibration on the small vessel model. J. UOEH, 8 (Suppl.): 109-117. (in Japanese)

Maki, T., Nakano, M., Fukagawa, Y., et al. (1986): Variation of liquid flow rate by oscillations. The 3rd Annual Meeting of the UOEH Association of Health Scienles: J. UOEH, 8: 135. (in Japanese) 


\section{細小管模型に基づく振動による流体流量変化の分析}

深川ゆかり1・大津ミキ1・中野 正博 2 牧 孝

1産業医科大学医療技術短期大学看護学科

2産業医科大学医療技術短期大学物理学教室

要 旨：職業病としての振動障害が, 様々な振動機具によって起こっている. 我々は, 単に末梢血 管を物理的に振動させた時の血流量の変化を知るために，モデル実験としてシリコン細管 を振動させ，その中を流れる水の流量の変化を測定した． 1-2000 Hzの振動数の 3 種類 の振動モードを与えた。水の流量は振動を加えると減少し, その減少は, 振動の種類およ び振動数に強く依存する事がわかった。この強い依存性の理由は，次のようである事を明 らかにした。まず振動によってシリコン管が伸縮し，管の平均の長さが，無振動時より長 くなる，そのため，管の平均の半径が，小さくなる，これによって，流量の減少が起こっ てくる．シリコン管の伸びは，振動の種類と振動数に強く依存するので，結局，流量に， 強い振動数依存性が見られる事を結論とした。

J. UOEH (産業医大誌), 8 ( 2 ): 159-168 (1986) 